\begin{tabular}{|l|l|l||}
\hline \multicolumn{2}{|c|}{ PublisherInfo } \\
\hline \hline PublisherName & $:$ & BioMed Central \\
\hline \hline PublisherLocation & $:$ & London \\
\hline \hline PublisherImprintName & $:$ & BioMed Central \\
\hline \hline
\end{tabular}

\title{
Monkey business
}

\begin{tabular}{|l|l|l||}
\hline \multicolumn{2}{|c|}{ ArticleInfo } \\
\hline \hline ArticleID & $:$ & 4450 \\
\hline \hline ArticleDOI & $:$ & $10.1186 /$ gb-spotlight-20020412-01 \\
\hline \hline ArticleCitationID & $:$ & spotlight-20020412-01 \\
\hline \hline ArticleSequenceNumber & $:$ & 116 \\
\hline \hline ArticleCategory & $:$ & Research news \\
\hline ArticleFirstPage & $:$ & 1 \\
\hline \hline ArticleLastPage & $:$ & 2 \\
\hline \hline & & RegistrationDate : 2002-4-12 \\
\hline ArticleHistory & $:$ & OnlineDate \\
\hline \hline ArticleCopyright & $:$ & BioMed Central Ltd2002-12 \\
\hline \hline ArticleGrants & $:$ & \\
\hline \hline ArticleContext & $:$ & 130593311 \\
\hline \hline
\end{tabular}




\section{Jonathan B Weitzman}

Email: jonathanweitzman@hotmail.com

Differences in gene expression levels might be sufficient to account for the behavioural and cognitive functions that distinguish us from monkeys. In the April 12 Science, Enard et al. address this issue by studying the transcriptome and proteome in human and chimpanzee tissues (Science 2002, 296:340-343). They compared mRNA levels in the brains and livers of six humans, six chimps (Pan troglodytes) and two orangutans (Pongo pygmaeus) using oligonucleotide microarrays representing about 12,000 human genes. Despite considerable variation between individuals, humans shared differences from the chimps particularly in the brain. Enard et al. observed a 5.5-fold acceleration of the rate of change in gene expression levels in human brains compared to chimpanzees or an outer group, macaque monkeys (Macaca mulatta). To confirm these species-specific changes they performed proteome analysis of brain tissues. Quantitative differences in protein levels were six times greater than qualitative changes in the human brain. The possible mechanisms governing these quantitative differences and their consequences provide food for thought.

\section{References}

1. Science, [http://www.sciencemag.org] 